\title{
PENERAPAN KUALITAS PELAYANAN PRAMUSAJI PADA PESISI RESTORAN DI THE ALANTARA SANUR
}

\author{
Komang Ratih Tunjungsari ${ }^{1}$, Putu Ayu Indra Swari ${ }^{2}$ \\ ${ }^{12}$ Institut Pariwisata dan Bisnis Internasional \\ Email: ratih.tunjung@ipb-intl.ac.id, ayuindra.swari00@gmail.com
}

\begin{abstract}
ABSTRAK
Penelitian ini dilakukan di The Alantara Sanur yang beralamat di Jalan Tirta Ening No. 12, Sanur Kauh, Denpasar, Bali. Penelitian ini bertujuan untuk mengetahui bagaimana penerapan kualitas pelayanan pramusaji pada Pesisi Restoran di The Alantara Sanur. Teknik sampling yang digunakan adalah Quota Sampling, dengan sampel yang digunakan yaitu 1 manajer restoran, 2 pramusaji, dan 20 tamu Pesisi Restoran. Teknik pengumpulan data yang digunakan berupa kuesioner, wawancara, observasi, dan juga dokumentasi. Teknik analisis data yang digunakan yaitu deskriptif kuantitatif. Dari hasil penelitian diketahui bahwa penerapan kualitas pelayanan yang dilakukan oleh pramusaji Pesisi Restoran dinilai sangat baik oleh tamu berdasarkan kuesioner dengan nilai 4,44 yang dikategorikan sangat baik dan data tersebut didukung oleh hasil wawancara, observasi, dan juga guest comment.
\end{abstract}

Kata kunci: Kualitas Pelayanan Pramusaji

\begin{abstract}
This research was conducted at The Alantara Sanur which is located at Tirta Ening Street No. 12, Sanur Kauh, Denpasar, Bali. This research is for people who know how to service the waiter at Pesisi Restaurant in The Alantara Sanur. Sampling technique where the sampling quota, with the sample used is 1 restaurant manager, 2 waiters, and 20 guests Pesisi Restaurant. Data collection techniques which are questionnaires, drawings, observations, and also good names. Data analysis techniques which use quantitative descriptive. From the results of the study know, which name is done by waiter Pesisi Restaurant is very good by guests are questionnaires with a score of 4.44 which is very well categorized and the data by leaders by career results, observations, also and guest comments.
\end{abstract}

Keywords: Waiter Service

PENDAHULUAN 
Pulau Bali merupakan salah satu pulau di Indonesia yang diminati oleh wisatawan domestik maupun internasional. Bali memiliki sektor pariwisata yang melimpah dan memiliki daya tarik tersendiri, seperti tradisi dan kebudayaan bali yang menjadi salah satu penyebab Bali menjadi daerah tujuan wisata. Menurut Wardhani (2018) wisatawan asal Australia tercatat menjadi wisatawan mancanegara (wisman) yang paling banyak berkunjung ke Bali. Data dari Badan Pusat Statistik (BPS) menyebutkan bahwa sepanjang tahun 2017, sebanyak 1,117,933 wisatawan Australia berlibur di Bali. Posisi nomor dua dan tiga ditempati oleh wisatawan mancanegara dari RRC dan Jepang. Akhir tahun selalu menjadi waktu favorit bagi para turis dari luar negeri untuk menghabiskan waktu di Bali. Bali menyumbangkan hampir setengah $(40.5 \%)$ dari keseluruhan wisatawan mancanegara yang berkunjung ke Indonesia, Bahkan tidak jarang bila masyarakat luar negeri lebih mengenal Bali ketimbang Indonesia sendiri. Salah satu daerah pariwisata di Bali yang banyak dikunjungi oleh wisatawan yaitu Sanur.

Sanur merupakan salah satu daerah tujuan wisata yang diminati oleh wisatawan. Salah satu tempat favorit wisatawan di Sanur yaitu Pantai Sanur. Menurut Suadnyana (2020) Pantai Sanur merupakan salah satu objek wisata pantai pasir putih yang sangat terkenal di pulau Bali. Setiap hari Pantai Sanur selalu ramai dengan kunjungan wisatawan, baik wisatawan asing maupun wisatawan Indonesia. Pantai Sanur menawarkan pemandangan matahari terbit. Oleh karena itu Pantai Sanur memiliki nama lain, yaitu Pantai Matahari Terbit. Sanur juga menyediakan sarana akomodasi seperti hotel sebagai tempat tinggal sementara wisatawan selama berlibur di Bali, salah satunya yaitu The Alantara Sanur Hotel.

Hotel adalah kebutuhan akan sarana akomodasi yang menyediakan fasilitas dan pelayanan penginapan, makanan, minuman, serta jasa lainnya yang dikelola secara profesional. Selain itu hotel dapat diartikan sebagai jasa yang menyediakan kamar untuk tempat menginap tamu, makanan, minuman, dan fasilitas-fasilitas lain yang diperlukan untuk mendapatkan keuntungan. Hotel identik dengan pelayanan, baik itu dalam hal melayani dan menangani tamu yang ingin memesan kamar, pelayanan kamar, pelayanan di restaurant, dan pelayanan di fasilitas lain yang terdapat di hotel. Suatu pelayanan harus dilakukan dengan baik dan dengan maksimal, setiap karyawan hotel harus bisa dan mampu dalam hal melayani tamu sesuai dengan prosedur atau SOP yang berlaku di hotel tempat ia bekerja.

Meningkatnya persaingan antar hotel menyebabkan masing-masing hotel berusaha memberikan kualitas dan pelayanan yang terbaik kepada konsumennya. Suatu perusahaan jasa perhotelan dapat dikatakan sukses apabila sudah mampu memberikan service atau pelayanan yang dapat memenuhi atau melebihi dari harapan konsumen (Kotler (2002:83). Kualitas Pelayanan (service quality) merupakan suatu hal yang penting untuk diperhatikan oleh suatu usaha perhotelan, karena perhotelan merupakan salah satu usaha jasa pelayanan yang tidak mudah pengelolaannya dalam memberikan fasilitas dan pelayanan yang baik bagi tamutamunya. Kualitas pelayanan dapat diketahui dengan cara membandingkan persepsi para tamu atas pelayanan yang mereka terima dengan pelayanan yang mereka harapkan terhadap pelayanan suatu hotel. 
Pelayanan harus dilakukan sedemikian rupa sesuai dengan SOP yang berlaku, meningkatkan kualitas pelayanan sangatlah penting bagi setiap hotel, tujuannya antara lain untuk mendapat kepuasan tamu sehingga tamu memiliki loyalitas yang tinggi terhadap hotel. Untuk menciptakan pelayanan yang berkualitas, setiap karyawan yang ada di hotel harus diberi pelatihan terlebih dahulu mengenai bagaimana cara melayani tamu dengan baik dan benar sesuai SOP. Selain itu, karyawan hotel juga harus memberikan pelayanan ekstra kepada setiap tamu yang datang tanpa melihat status dari tamu tersebut. Jika ada tamu yang komplain, pihak hotel harus segera mengatasi komplain tersebut dengan benar sesuai prosedur. Jika semua hal itu sudah diterapkan di hotel, maka setiap tamu akan merasa puas dengan pelayanan hotel dan membuat tamu memiliki rasa loyalitas tinggi terhadap hotel.

Pelayanan dalam dunia perhotelan merupakan kegiatan yang mengedepankan tentang sikap hospitality yang menjadikan tamu yang datang untuk menginap menjadi nyaman dan senang, serta akan kembali bila tamu mendapatkan kesan baik dan puas atas pelayanan yang diberikan oleh hotel tersebut. Setiap pelayanan yang diberikan di hotel maupun di restoran khususnya, biasanya memiliki prosedur kerja sendiri. Prosedur kerja ini bukan hanya diterapkan dalam pelayanan, namun juga dilakukan mulai saat sebelum restoran buka, saat operasional, dan sampai saat restoran tutup.

The Alantara Sanur merupakan salah satu hotel yang berlokasi di Jl. Tirta Ening No 12, Sanur Kauh, Denpasar, Bali. The Alantara Sanur memiliki beberapa departemen yang saling membantu untuk kelancaran kegiatan operasional. Salah satunya adalah Food and Beverage Department (Departemen Makanan dan Minuman). Departemen ini merupakan salah satu bagian yang ada di dalam hotel yang bertugas menyediakan dan menyajikan makanan dan minuman untuk tamu hotel (in-house) maupun tamu luar hotel.

Food and Beverage Department di The Alantara Sanur membawahi beberapa sub bagian yaitu Food and Beverage Product dan Food and Beverage Service. Dalam hal menyediakan dan menjual makanan dan minuman di restoran diperlukan petugas yang bertanggung jawab untuk melayani hal tersebut yaitu pramusaji. Restoran sebagai tempat menjual makanan dan minuman yang berusaha memenuhi harapan dan kebutuhan tamu akan makan dan minum, sangatlah penting memperhatikan pramusaji yang berperan untuk mencapai kepuasan tamu. Pekerjaan dalam bidang pelayanan makanan dan minuman merupakan kegiatan yang berantai dan saling berkaitan. Pramusaji sebagai ujung tombak pelayanan harus bersifat cooperative dan conscientious, yang artinya selalu mengutamakan kerjasama serta memiliki sifat yang teliti. Kejujuran, ramah tamah, serta smiling appearance merupakan sikap yang harus ditunjukkan oleh setiap pramusaji.

Terkait dalam usahanya memberikan pelayanan makanan dan minuman secara maksimal kepada setiap tamu, pihak manajemen restoran yaitu Pesisi Restoran di The Alantara Sanur mencatat segala guest comment yang diberikan oleh tamu mengenai pelayanan. Guest comment diperoleh dengan cara ketika tamu berada di restoran maka pramusaji bertanggung jawab menanyakan tamu mengenai 
kualitas pelayanan. Sehingga seluruh komentar tamu akan dicatat dan dianalisis sebagai bahan acuan untuk evaluasi terhadap pelayanan yang telah diberikan.

Dilihat dari bad guest comment pada lampiran 1, terdapat salah satu contoh bad comment yang mengacu pada bad service yang diterima oleh tamu atas nama Diah Harniek, tamu mengatakan "I got bad service from the waiter at the restaurant, the waiter was not friendly, I felt ignored, really the service was not good, I'm not sure I will come back again". Berdasarkan dari bad comment di atas, hal tersebut tentu saja membuat tamu untuk berpikir kedua kalinya untuk kembali lagi, karena dari pengalaman sebelumnya ia mendapat service yang kurang bagus sehingga itu berpengaruh terhadap loyalitas tamu tersebut. Oleh karena itu, dapat disimpulkan bahwa kualitas pelayanan harus lebih diutamakan dan dimaksimalkan, karena kualitas pelayanan menjadi suatu ikon utama dalam industri perhotelan dan dapat mempengaruhi loyalitas tamu.

Berdasarkan latar belakang diatas didapatkan rumusan permasalahan yang akan diteliti yaitu mengacu pada bagaimana penerapan kualitas pelayanan pramusaji pada Pesisi Restoran di The Alantara Sanur. Dengan tujuan dari penelitian ini yaitu untuk mengetahui bagaimana penerapan kualitas pelayanan pramusaji pada Pesisi Restoran di The Alantara Sanur.

\section{ANALISIS TEORITIS}

Sumber daya manusia kini makin berperan besar bagi kesuksesan suatu organisasi. Banyak organisasi yang menyadari bahwa unsur manusia dalam suatu organisasi dapat memberikan keunggulan bersaing. Mereka membuat sasaran, strategi, inovasi untuk mencapai tujuan organisasi. Oleh karena itu, sumber daya manusia merupakan salah satu unsur yang paling vital bagi organisasi. Menurut Rivai dalam Candraswari (2019) menyatakan "Sumber daya manusia adalah seorang yang siap, mau, dan mampu memberi sumbangan usaha pencapaian tujuan organisasi". Dengan demikian dapat disimpulkan bahwa sumber daya manusia merupakan sekelompok manusia yang memiliki kemampuan bekerja untuk mencapai suatu tujuan perusahaan dengan menggunakan potensi psikis dan fisik yang dimilikinya secara maksimal, sehingga keberadaan unsur manusia dalam suatu organisasi merupakan hal yang sangat penting dalam suatu organisasi.

Salah satu sarana untuk melaksanakan food service industry adalah restoran. Dalam hal ini restoran yang ada dalam suatu hotel bukan hanya untuk memenuhi tamu-tamu hotel, tetapi juga menerima tamu-tamu dari luar hotel yang tidak ada kaitannya dengan akomodasi yang tersedia. Menurut Marsum dalam Dewi (2014:8) restoran merupakan suatu tempat atau bangunan yang diorganisasikan secara komersial, yang menyelenggarakan pelayanan dengan baik kepada tamunya baik berupa makanan maupun minuman. Sedangkan menurut Agusnawar dalam Dewi (2014:9) menyatakan bahwa "Restoran adalah suatu usaha komersial yang menyediakan usaha pelayanan makanan dan minuman bagi umum dan dikelola secara profesional". Sehingga dapat disimpulkan bahwa restoran secara umum dapat didefinisikan sebagai ruang atau tempat yang diorganisir secara komersil untuk menyelenggarakan pelayanan berupa makan dan minum yang tersedia di 
dalamnya, maka restoran dalam sebuah perusahaan hotel merupakan sarana penjualan dan penyajian makanan dan minuman dalam sebuah hotel.

Menurut Marsum dalam Dewi (2014:9) mengemukakan definisi pramusaji dengan menyatakan "Pramusaji adalah karyawan / karyawati di sebuah restoran yang bertugas menunggu tamu-tamu, membuat tamu-tamu merasa mendapat sambutan yang baik dan nyaman, mengambil pesanan makanan dan minuman serta menyajikannya, juga membersihkan restoran dan lingkungannya serta mempersiapkan meja makan (table setting) untuk tamu berikutnya". Menurut Sugiarto dalam Dewi (2014:9) pramusaji adalah "Karyawan restoran atau room service yang memiliki tugas dan tanggung jawab memberikan pelayanan akan kebutuhan makan dan minum bagi tamu hotel". Dari beberapa definisi diatas maka dapat disimpulkan bahwa pramusaji adalah karyawan dalam sebuah restoran yang mempunyai tugas dan tanggung jawab melayani kebutuhan makanan dan minuman bagi para pelanggan restoran secara profesional.

Sebagai seorang yang berhubungan langsung dengan tamu dan merupakan ujung tombak usaha food and beverages dalam menjalankan tugasnya, yaitu melayani tamu dan menyajikan makanan dan minuman di restoran, seorang pramusaji dituntut untuk memenuhi persyaratan dan syarat-syarat untuk seorang pramusaji yang diklasifikasi oleh kriteria pramusaji yang baik menurut Marsum dalam Prabawati (2019:11) seorang pramusaji yang baik memiliki kriteria sebagai berikut:

1. Mempunyai kesadaran sosial yang tinggi.

2. Mempunyai sifat dan kebiasaan-kebiasaan yang baik.

3. Bisa berkomunikasi secara efektif dengan para tamu.

4. Mempunyai pribadi yang menyenangkan, ramah, dan sopan.

5. Berjiwa pedagang yang ulung.

6. Selalu bersedia untuk melayani para tamu, dan sebagainya.

Menurut Shahrim dalam Setyadi (2019:19), tugas dan tanggung jawab pramusaji adalah:

1. Bersopan santun terhadap tamu atau pelanggan dan para sesama pekerja.

2. Senantiasa ber-uniform lengkap rapi dan bersih.

3. Mengikuti jadwal kerja yang telah ditetapkan dan menepati masa kerja tersebut.

Wiwoho dalam Setyadi (2019:19) menyatakan bahwa tugas dan tanggung jawab seorang waiter atau waitress sebagai berikut:

1. Tugas:

a) Mempersiapkan dining room atau restoran.

b) Menyambut tamu dan mempersilahkan tamu untuk duduk.

c) Mengambil pesanan tamu.

d) Mengambil makanan dan minuman.

e) Menyajikan makanan dan wine.

f) Menunjukan restoran guest bill (tagihan).

g) Menerima pembayaran dari tamu. 
h) Mengucapkan terimakasih kepada tamu yang telah selesai makan dan meninggalkan restoran.

i) Membersihkan meja dan resetting meja seperti semula.

2. Tanggung Jawab:

a) Menjaga penampilan diri (personal grooming).

b) Berkelakuan baik

Menurut Rymbertus dalam Dewi (2014:12), standar operasional prosedur (SOP) pramusaji adalah sebagai berikut:

1. Menyiapkan service station untuk mise en place.

2. Menyambut dan menyapa tamu.

3. Mengantarkan tamu dan membantu tamu duduk diatas kursi.

4. Membuka dan menempatkan napkin di pangkuan tamu.

5. Memberikan daftar menu dan menyarankan menu.

6. Menuangkan air es.

7. Menerima pesanan makanan

Berdasarkan data yang diperoleh dari manajer Pesisi Restoran The standar operasional prosedur pramusaji di Pesisi Restoran adalah sebagai berikut:

1. Welcoming the guest

Adapun indikator-indikator dalam welcoming the guest yaitu:

a) Menyambut tamu sesuai greetings standar Pramana Experience.

b) Tamu di sapa dengan ramah, kontak mata dan senyum.

c) Tamu di sapa saat 5 detik dari kedatangannya..

d) Dengan segera dekati tamu dengan melangkah kedepannya Jika saat itu masih melayani tamu, sampaikan kepada tamu tersebut : "Saya akan segera kembali , Bapak/Ibu"

2. Greeting the guest

Adapun indikator-indikator dalam greeting the guest yaitu:

a) Gunakan sapaan yang benar sesuai dengan standar Pramana.

b) Panggil mereka dengan sapaan yang benar sesuai dengan waktunya: selamat pagi $(00.00-11.59)$, selamat siang/sore $(12.00-17.59)$, selamat malam $(18.00-23.59)$.

c) Usahakan menyebutkan nama tamu kalau tahu, "Selamat pagi Bapak XYZ, apa kabar?"

3. Escorting the guest

Adapun indikator-indikator dalam escorting the guest yaitu:

a) Cek jika ada reservasi.

b) Dengan sopan tanyakan kepada tamu apakah ada reservasi, jika ya, cek nama tamu dan nomor kamar dan segera mengantar mereka ke meja. 
c) Jika tidak ada reservasi, tanya tentang meja kesukaannya, area merokok atau tidak merokok, tanyakan"Apakah Bapak/Ibu memilih meja di area merokok, atau tidak?"

d) Antarkan tamunya ke meja, jaga jarak sekitar 3 langkah and pastikan tamu mengikuti dari belakang.

e) Tanyakan kepada tamu apakah ia setuju dengan meja tersebut.

f) Tarik kursi untuk tamu duduk, dahulukan wanita yang lebih tua.

g) Tarik kursi untuk memudahkan tamu duduk dan kemudian dorong kembali ke depan ketika tamu hendak duduk.

h) Setelah tamu duduk, tinggalkan meja dengan berkata "Selamat menikmati makan siang/malam, Bapak/Ibu".

\section{Presenting the menu}

Adapun indikator-indikator dalam presenting the menu yaitu:

a) Siapkan satu daftar makanan untuk setiap tamu.

b) Pastikan bahwa daftar makanan dalam keadaan baik dan bersih.

c) Buka daftar makanan dan berikan kepada tamu dari sebelah kanan.

d) Jangan membagikan daftar makanan dalam satu tempat. Kita harus mendekati setiap tamu ketika memberikan daftar makanan.

e) Berikan kepada wanita terlebih dahulu, tuan rumah terakhir, Katakan,"Daftar makanannya Pak/Bu”.

f) Tawarkan special hari ini kepada tamu, katakan "Spesial kami hari ini........ Bapak/Ibu mau mencobanya?".

\section{Taking the order}

Adapun indikator-indikator dalam taking the order yaitu:

a) Siapkan kapten order coretan dan pena hotel untuk mencatat.

b) Dekati tamu dimulai dari wanita terlebih dahulu dan tuan rumah yang terakhir dengan memutar searah jarum jam untuk mengurangi pergerakan. Menjaga posisi tetap menghadap ke arah tamu dalam satu meja. Menanyakan/menawarkan kepada tamu minuman sebelum memulai makan dengan berkata "Pak/bu, mau pesan minum apa sebelum pesan makanan?".

c) Mengambil pesanan dengan berkata "Bisa saya catat pesanannya, pak/bu?" Jika tamu belum siap untuk memesan, berikan tamu beberapa masukan dengan berkata "Mungkin bapak/ibu mau mencoba makanan spesial kita hari ini".

d) Mengusulkan dalam penjualan, "Apakah ingin dipesankan sebotol air mineral?".

e) Menulis di captain order.

f) Semua jenis pesanan ditulis dengan singkat, jelas dan mudah untuk dibaca. 
g) Mengulang pesanan dan terima kasih ke tamu.

h) Mengulang pesanan tamu secara perorangan atau menyebutkan semua pesanan secara bersama-sama, dengan mengatakan"Bisa saya ulang pesanan bapak/ibu? Satu Caesar salad untuk ibu dan satu gado-gado untuk bapak. Terima kasih".

i) Masukan semua pesanan ke dalam saluran POS.

j) Jika sistemnya sudah satu jalur, pesanan akan tercetak di dapur dan tempat pembuatan minuman. Pastikan dalam memasukkan pesanan secara benar penting sekali untuk menghindari keterlambatan dan reputasi yang tidak baik.

\section{Serving beverages}

Adapun indikator-indikator dalam serving beverages yaitu:

a) Semua minuman akan disiapkan dari Service Bar.

b) Bartender tidak akan mengeluarkan minuman jika tidak ada captain order atau kertas cetakan dari mesin kasir/POS.

c) Semua minuman disajikan sesuai dengan dengan standar hotel.

d) Minuman botol/kaleng harus dituang di depan tamu.

e) Semua minuman campuran tidak beralkohol di sajikan dengan sedotan kecuali air mineral.

f) Semua minuman disajikan dengan alas minum, kecuali untuk gelas berkaki.

g) Buka tutup botol/kaleng di depan tamu, ambil tutupnya dan tuangkan ke gelas tamu, botol ditinggalkan di meja.

h) Minuman dingin dan hangat di sajikan dengan gelas, untuk minuman panas disajikan dengan pot / cangkir.

i) Untuk minuman beralkohol atau minuman campuran, waiter harus ditanyakan kepada tamu tentang cara penyajiannya, seperti dengan es, tanpa es, beku dan lain sebagainya.

7. Adjusting cutlery

Adapun indikator-indikator dalam adjusting cutlery yaitu:

a) Jika tamu telah memesan dan telah di masukkan dalam mesin kasir/POS, pramusaji harus segera menyesuaikan peralatan makan di meja sesuai dengan pesanan tamu.

b) Siapkan satu piring dilapisi dengan lipatan serbet.

c) Siapkan peralatan makan yang sesuai dari service station dan di letakkan di atas piring.

d) Melangkah ke meja tamu, letakkan piring dengan peralatan makan di tangan kiri dan tata peralatan yang sesuai dari sebelah kanan tamu, wanita dulu dan searah jarum jam

e) Tata dengan rapi di meja dengan jarak $2 \mathrm{~cm}$ dari ujung meja. 
f) Tata peralatan sesuai dengan urutan penyajian peralatan makan untuk makanan pembuka di pasang di bagian luar dan diikuti dengan peralatan makan untuk makanan utama.

g) Sendok, pisau harus di letakkan di sebelah kanan dan garpu di sebelah kiri.

h) Ketika tamu memesan makanan penutup bersamaan dengan yang lainnya, jangan pasang peralatan makannya. Lakukan setelah selesai membersihkan meja.

i) Untuk pesanan ice cream, peralatan makan tidak di pasang di meja tetapi diletakkan bersamaan dengan ice cream.

\section{Serving food}

Adapun indikator-indikator dalam serving food yaitu:

a) Periksa peralatan makanan.

b) Sebelum menghidangkan makanan ke meja, pastikan bahwa semua yang di meja telah siap.

c) Semua peralatan makan telah di tata sesuai dengan pesanan dan makanan sebelumnya telah diangkat.

d) Mengambil makanan dari dapur.

e) Sebelum cek makanan, cek dulu hasil cetak pesanan, dahulukan makanan ke tamu wanita.

f) Bawa makanan ke station pelayanan dengan tray, jika diperlukan.

g) Bawa tray dengan tangan kiri atau kanan diletakkan di tengah tray. Jika traynya besar, gunakan dua tangan.

h) Sajikan makanan.

i) Cek kembali pesanannya dengan hasil cetak pesanan di stasiun, pastikan semua pesanan tamu sesuai dengan apa yang di pesan.

j) Sajikan ke tamu wanita terlebih dahulu, tuan rumah terakhir dari sebelah kanan dengan menggunakan tangan kanan. Sajikan searah jarum jam sesuai dengan posisi tempat duduk tamu.

k) Sebutkan nama item pesanan dan juga permohonan spesial dari tamu, katakan, "Permisi Bapak/Ibu, Spaghetti Carbonara anda" tanpa ham (jika ada permohonan spesial).

1) Pastikan semua makanan pada meja tersebut telah dihidangkan.

m)Cek kembali semua makanan dengan kertas pesanan tamu.

n) Jika ada kesalahan, segera informasikan secepatnya kepada Kepala koki, jangan pernah berdebat dengan tamu atau dengan Kepala Koki.

o) Informasikan kepada tamu tentang keterlambatan makanan dan minta maaf.

p) Hidangkan makanan penunjang dari sebelah kiri tamu. 
q) Jika diminta oleh tamu dan itu adalah bagian dari makanan, ambil makanan untuk kedua kalinya dari dapur dan sajikan dari sebelah kiri tamu.

9. Checking the guest satisfaction

Adapun indikator-indikator dalam checking the guest satisfaction yaitu:

a) Cek tentang kepuasan tamu atas makanan maksimal dua kali.

b) Dekati tamu ketika mereka telah memakan hidangan utama dan/atau makanan yang spesial makanannya selama 15 detik atau setelah gigitan pertama dari tamu.

c) Mendekati meja tamu dengan senyum dan kontak mata.

d) Tanya dengan tamu, "Bagaimana makanan/minumannya bapak/ibu?".

e) Apabila tamu puas dengan makanannya, katakan "Terima kasih, Bapak/Ibu, selamat menikmati makan siang/makan malamnya".

f) Jika tamunya kecewa dengan makanannya, sampaikan permintaan maaf dengan mengatakan "Mohon maaf Bapak/Ibu, apa yang salah dari makanan tersebut?".

g) Tawarkan solusi dengan minta persetujuan tamu dulu, "Bisa saya ........ makanannya?". Solusi yang kita tawarkan tergantung pada masalahnya.

10. Clearing the soiled plate

Adapun indikator-indikator dalam clearing the soiled plate yaitu:

a) Angkat piring dari tamu wanita dahulu dan tuan rumah terakhir.

b) Lakukan dari sebelah kanan tamu searah jarum jam, katakan "Boleh saya angkat piringnya Ibu/Bapak?”.

c) Ambil piring pertama dengan tangan kanan dan letakkan di tangan kiri.

d) Piring kedua di pergelangan tangan.

e) Letak garpu makanan pembuka dengan posisi diagonal/miring.

f) Masukan pisau makanan pembuka di bawahnya.

g) Letak garpu yang lainnya di atasnya.

h) Sapukan sisa makanan ke piring yang pertama.

i) Letakkan piring ketiga diatas piring kedua.

j) Lakukan hal sama seperti diatas sampai semua piring terangkat.

11. Crumbing the table

Adapun indikator-indikator dalam crumbing the table yaitu:

a) Siapkan kain lap atau pena pembersih meja dan $B \& B$ plate untuk membersihkan meja.

b) Lipat kain sebanyak 4 kali dan bentuk menjadi bentuk kotak kecil.

c) Pegang $B \& B$ plate dengan tangan kiri untuk melakukan crumbing.

d) Pastikan semua piring telah diangkat dari meja sebelum membersihkannya.

e) Sapu semua serbuk dan bekas makanan ke atas $B \& B$ plate. 
f) Gunakan ujung yang terbuka dari kain lap untuk menyapu serbuk.

g) Sapu dengan perlahan dan lembut dari tengah ke pinggir meja.

h) Angkat tempat garam dan merica.

i) Bersihkan $B \& B$ plate dan selalu pastikan kebersihannya sebelum digunakan.

12. Offering next meal

Adapun indikator-indikator dalam offering next meal yaitu:

a) Siapkan pengetahuan tentang produk yang akan dijual.

b) Bangun kepercayaan diri.

c) Selalu berpikiran bahwa kita adalah seorang penjual.

d) Waktu membersihkan meja, waiter harus menanyakan kepada tamu jika mereka ingin makanan penutup/kopi/teh atau makanan yang lain setelah makan dengan bertanya "Mau makanan penutupnya pak/bu, kopi/teh atau yang lain" atau menyarankan minuman setelah makan.

e) Jangan memaksa tamu untuk membeli.

13. Serving coffee and tea

Adapun indikator-indikator dalam serving coffee and tea yaitu:

a) Untuk breakfast, teh dan kopi disajikan pertama tama atau bisa tergantung dari permintaan tamu. Waiter sebaiknya juga menanyakan ke tamu untuk waktu penyajian toast dan kopi serta teh.

b) Kopi akan di sajikan fresh dari poci kecil (atau secangkir kopi).

c) Teh akan dihidangkan dari beberapa pilihan teh yang dipilih sendiri oleh tamu.

d) Waiter akan membawa ceret dengan air panas dan teh yang telah dipilih di atas tatakan kemudian akan menanyakan kepada tamu apakah tehnya mau kental atau encer. Setelah disajikan, angkat kantong tehnya dan letakkan diatas piring kecil di tray.

14. Presenting the bill

Adapun indikator-indikator dalam presenting the bill yaitu:

a) Ketika tamu sudah ada tanda bahwa tidak ada lagi pesanan tambahan, maka segera siapkan bill nya.

b) Makanan yang dikonsumsi harus di masukan ke POS dengan tepat.

c) Berikan bill kepada tamu yang minta.

d) Cek makanan yang tertera dalam bill cocokkan dengan dengan pesanan yang tertulis di captain order atau secarik kertas bekas.

e) Letakkan bonnya di dalam tatakan bon beserta dengan pena hotel dan berikan kepada tamu. Katakan: Permisi, bill nya, Ibu/Bapak”.

\section{Handling payment}

Adapun indikator-indikator dalam handling payment yaitu:

a) Tamu akan memutuskan sendiri cara pembayaran. 
b) Untuk tagihan kamar (room charge), tamu cukup menuliskan nama, nomor kamar dan tanda tangan.

c) Untuk kartu kredit, kita hanya menerima kartu kredit yang terkenal, seperti Visa dan Master (berdasarkan peraturan hotel).

d) Untuk tagihan perusahaan (jika mereka mempunyai perjanjian dengan departemen reservasi dan bagian penjualan). Tamu yang mengatasnamakan perusahaan, harus tanda tangan dan akan di masukan di dalam tagihan kamarnya. front office akan memasukkannya bill nya dalam akun tersendiri.

e) Jika cash, waiter/ess menghitung dahulu uang cash, sebelum diproses ke kasir dan mengembalikan uang kembalian kepada tamu sesegera mungkin, bill tamu harus diproses segera dan selambat-lambatnya 3 menit.

f) Selalu sampaikan terima kasih kepada tamu.

Kualitas pelayanan dapat diartikan sebagai tingkat kepuasan tamu atau konsumen. Jenis kualitas pelayanan yang baik adalah jenis pelayanan yang memuaskan dan sesuai dengan pelayanan yang diharapkan oleh konsumen. Namun, jika layanan ini dapat melampaui harapan konsumen, maka jenis kualitas pelayanan ini dapat dikategorikan sebagai pelayanan yang sangat berkualitas atau sangat memuaskan. Kualitas pelayanan ini menjadi penting karena akan berdampak langsung pada citra hotel. Kualitas pelayanan yang baik akan menjadi sebuah keuntungan bagi hotel. Menurut Wyckof dalam Prabawati (2019:7) berpendapat bahwa kualitas jasa merupakan tingkat keunggulan (excellent) yang diharapkan dalam pengendalian atas keunggulan tersebut untuk memenuhi keinginan pelanggan.Dari paparan pengertian kualitas pelayanan diatas, maka dapat disimpulkan bahwa kualitas pelayanan merupakan suatu proses pelayanan yang diberikan kepada tamu dengan memberikan pelayanan yang maksimal sesuai prosedur agar dapat memenuhi harapan tamu dan dapat menciptakan kepuasan tamu sehingga tamu memiliki loyalitas yang tinggi.

Menurut Parasuraman dalam Setyadi (2019:12) kualitas pelayanan dapat dilihat dari lima dimensi antara lain:

1. Bukti Langsung (Tangibles)

Kemampuan suatu perusahaan dalam menunjukan eksistensinya kepada pihak eksternal.

2. Keandalan (Reliability)

Kemampuan perusahaan untuk memberikan pelayanan sesuai dengan yang dijanjikan secara akurat dan terpercaya.

3. Ketanggapan (Responsiveness)

Suatu kebijakan untuk membantu dan memberikan pelayanan yang cepat (responsif) dan tepat kepada pelanggan dengan penyampaian informasi yang jelas.

4. Jaminan (Assurance) 
Pengetahuan kesopansantunan, dan kemampuan para pegawai perusahaan untuk menumbuhkan rasa percaya para pelanggan kepada perusahaan.

5. Empati (Empathy)

Pemberian perhatian yang tulus dan bersifat individual atau pribadi yang diberikan kepada para pelanggan dengan berupaya memahami keinginan konsumen.

Pada dasarnya cukup banyak karakteristik suatu pelayanan dimana karakteristik pelayanan mempunyai kekuatan untuk mempengaruhi tingkat kepuasan dan penampilan kerja karyawan. Menurut Simamora dalam Dewi (2014) karakteristik pelayanan terdiri atas empat, yaitu:

1. Intangibility (tidak berwujud)

Layanan yang bersifat intangibility artinya tidak dapat dilihat, dirasa, diraba, dicium, dan didengar sebelum dibeli. Seseorang tidak dapat menilai hasil dari layanan sebelum ia menikmatinya sendiri. Untuk mengurangi ketidakpastian, pembeli akan mencari tanda atau bukti dari kualitas jasa tersebut.

2. Inseparability (tidak terpisahkan)

Layanan biasanya dijual terlebih dahulu baru kemudian diproduksi dan dikonsumsi secara bersamaan. Jika seseorang melakukan layanan maka penyedianya adalah bagian dari layanan. Karena klien juga hadir pada saat layanan itu dilakukan, interaksi antara penyedia layanan dan pelanggan merupakan ciri khusus dalam pemasaran layanan.

3. Variability (bervariasi)

Layanan sangat bersifat variabel karena merupakan non standardized output, artinya banyak variasi bentuk, kualitas dan jenis, tergantung pada siapa, kapan dan dimana layanan tersebut dihasilkan.

4. Perishability (mudah lenyap)

Layanan merupakan komoditas yang tidak dapat tahan lama dan tidak dapat disimpan. Sehingga dapat dikatakan bahwa jasa dihasilkan pada saat ada permintaan akan jasa tersebut dan permintaan ini tidak dapat ditunda.

Berdasarkan pada pokok permasalahan yang telah dipermasalahkan, maka variabel dalam penelitian ini yaitu kualitas pelayanan. Kualitas pelayanan adalah upaya pemenuhan kebutuhan yang dibarengi dengan keinginan konsumen serta ketepatan cara penyampaiannya agar dapat memenuhi harapan dan kepuasan pelanggan tersebut (Tjiptono dalam Dewi, 2014). Adapun indikator dari variabel kualitas pelayanan menurut Parasuraman dalam Dewi (2014) adalah:

1. Kehandalan (reliability) adalah mengacu pada kemampuan untuk menyediakan layanan seperti yang dijanjikan secara teratur.

Adapun indikator-indikator reliability dalam penelitian ini adalah:

a. Ketepatan waktu pelayanan.

b. Standar pelayanan restoran.

c. Kesiapan pramusaji dalam melayani tamu.

2. Daya Tanggap (responsiveness) adalah kemampuan untuk merespon konsumen secara tepat. 
Adapun indikator-indikator responsiveness dalam penelitian ini adalah:

a. Tanggung jawab pramusaji.

b. Kemampuan memenuhi keinginan tamu.

c. Pramusaji menawarkan bantuan kepada tamu.

d. Kemampuan pramusaji menangani keluhan tamu.

3. Jaminan (assurance) adalah kemampuan untuk menumbuhkan kepercayaan konsumen terhadap perusahaan dan perusahaan bisa menciptakan rasa aman bagi para konsumennya.

Adapun indikator-indikator assurance dalam penelitian ini adalah:
a. Pengetahuan menu dari Pramusaji.
b. Kemampuan pramusaji dalam berbahasa asing.
c. Keterampilan pramusaji.
d. Keramahan pramusaji.

4. Empati (empathy) adalah kemampuan untuk memahami dan berhubungan dengan perasaan pelanggan.

Adapun indikator-indikator emphaty dalam penelitian ini adalah:

a. Kemampuan dalam berkomunikasi.

b. Kemampuan dalam memahami kebutuhan tamu.

c. Ketulusan dalam melayani tamu.

d. Perhatian pramusaji kepada tamu.

5. Bukti Fisik (tangibles) adalah ciri fisik dari pelayanan yang diberikan, seperti tampilan bangunan, kebersihan fasilitas, dan penampilan personel. Adapun indikator-indikator tangibles dalam penelitian ini adalah:
a. Kebersihan restoran.
b. Penampilan pramusaji.
c. Lokasi restoran.

\section{METODOLOGI}

Populasi adalah wilayah generalisasi yang terdiri dari objek atau subjek yang mempunyai kuantitas dan karakteristik yang ditetapkan oleh peneliti untuk dipelajari dan kemudian ditarik kesimpulannya (Sugiyono dalam Pantiyasa, 2013:87). Populasi dalam penelitian ini adalah 5 karyawan restoran yang terdiri dari 1 manajer dan 4 pramusaji. Dan 50 tamu pada Pesisi Restoran di The Alantara Sanur.

Sampel (sampling) adalah bagian dari populasi yang dapat mewakili seluruh populasi (Pantiyasa, 2013:87). Teknik sampel yang dipakai dalam penelitian ini adalah teknik penyampelan non probability sampling yaitu teknik pengambilan sampel yang tidak memberi peluang atau kesempatan yang sama bagi setiap anggota populasi untuk dipilih menjadi sampel (Pantiyasa, 2013:96). Selanjutnya digunakan teknik dengan cara quota sampling. Quota Sampling ini merupakan teknik untuk menentukan sampel dari populasi yang didasarkan atas jumlah yang 
ditentukan oleh peneliti (Pantiyasa, 2013:97). Dalam penelitian ini, sampel yang digunakan yaitu terdiri dari 1 manajer restoran, 2 pramusaji restoran, dan 20 tamu Pesisi Restoran di The Alantara Sanur.

Data kuantitatif adalah seluruh informasi yang dikumpulkan dari lapangan yang dinyatakan dalam bentuk angka atau diangkakan (Pantiyasa, 2013:67). Data kuantitatif yang digunakan dalam penelitian ini adalah data hasil kuesioner tentang penilaian tamu terhadap kualitas pelayanan pramusaji di Pesisi Restoran.

Data Kualitatif

Data kualitatif adalah data yang tidak terbentuk angka melainkan keterangan (Pantiyasa, 2013:68). Data kualitatif yang digunakan dalam penelitian ini adalah data yang berupa narasi dan didapatkan dari data guest comment, data wawancara dengan manajer restoran dan 2 pramusaji restoran, dan data observasi yang dilakukan oleh peneliti pada Pesisi Restoran di The Alantara Sanur.

Data primer adalah data yang dikumpulkan oleh peneliti langsung dan sumbernya dicatat, diamati pertama kalinya, kemudian diolah untuk menjawab permasalahan dalam penelitian (Pantiyasa, 2013:69). Data primer yang digunakan dalam penelitian ini adalah data hasil penyebaran kuesioner kepada tamu, data hasil wawancara dengan manajer restoran dan 2 pramusaji restoran, dan data hasil observasi pada Pesisi Restoran di The Alantara Sanur.

Data sekunder adalah data yang diperoleh peneliti dalam bentuk data yang sudah jadi bukan dari hasil mengumpulkan dan mengolah sendiri (Pantiyasa, 2013:69). Data sekunder dalam penelitian ini adalah data guest comment Pesisi Restoran di The Alantara Sanur.

Teknik pengumpulan data yang digunakan dalam penelitian ini adalah:

Kuesioner

Kuesioner adalah teknik pengumpulan data dengan cara menyusun daftar pertanyaan yang terinci dan lengkap dalam suatu daftar pertanyaan (Pantiyasa, 2013:82). Jenis kuesioner yang digunakan dalam penelitian ini adalah kuesioner tertutup atau berstruktur, yaitu pertanyaan yang diajukan kepada responden disertai dengan pilihan jawaban, responden tinggal memilih jawaban yang telah tersedia. Kuesioner akan disebarkan kepada 20 tamu yang berada di Pesisi Restoran di The Alantara Sanur. Dalam kuesioner ini menggunakan Skala Likert, yaitu skala yang digunakan untuk mengukur sikap, pendapat, dan persepsi seseorang atau sekelompok orang tentang fenomena sosial (Sugiyono, 2014: 132). Dalam penelitian, fenomena sosial ini telah ditetapkan secara spesifik oleh peneliti, yang selanjutnya disebut sebagai variabel penelitian. Setiap jawaban kuesioner mempunyai bobot atau skor nilai dengan skala likert, sebagai berikut:

1. Untuk jawaban SB, sangat baik dengan skor 5

2. Untuk jawaban B, baik dengan skor 4

3. Untuk jawaban $\mathrm{C}$, cukup dengan skor 3

4. Untuk jawaban TB, tidak baik dengan skor 2

5. Untuk Jawaban STB, sangat tidak baik dengan skor 1

Dokumentasi

Dokumentasi adalah teknik pengumpulan data dengan melakukan pencatatan data melalui dokumen-dokumen yang relevan (Pantiyasa, 2013:85). 
Dalam penelitian ini, dokumentasi yang digunakan adalah dokumentasi dari data guest comment Pesisi Restoran.

Wawancara

Wawancara merupakan teknik pengumpulan data yang dilakukan secara lisan oleh peneliti dengan cara mengadakan tanya jawab dengan responden (Pantiyasa, 2013:79). Dalam penelitian ini, wawancara dilakukan dengan manajer restoran pada Pesisi Restoran dan beberapa pramusaji Pesisi Restoran di The Alantara Sanur

Observasi

Observasi adalah studi yang disengaja dan sistematis tentang keadaan atau fenomena sosial dan gejala psikis dengan sengaja mengamati dan mencatat (Pantiyasa, 2013:78). Jenis observasi yang dilakukan dalam penelitian ini adalah observasi partisipatif yaitu peneliti terlibat langsung dan berperan aktif dalam kegiatan yang menjadi objek pengamatan yang dilakukan oleh sumber data (Pantiyasa, 2013:78). Dalam penelitian ini, peneliti berposisi sebagai trainee food and beverage service pada Pesisi Restoran di The Alantara Sanur.

Penelitian ini menggunakan teknik analisis data yaitu deskriptif kuantitatif yang digunakan untuk menganalisis data dengan cara mendeskripsikan atau menggambarkan data yang telah dikumpulkan dari jawaban responden dari pertanyaan tentang penerapan kualitas pelayanan pramusaji pada Pesisi Restoran di The Alantara Sanur.

\section{HASIL PENELITIAN}

Dibawah ini merupakan penjelasan mengenai data penerapan kualitas pelayanan pramusaji yang didapat dari hasil penelitian yang dilakukan dengan menyebar 20 kuesioner kepada tamu Pesisi Restoran di The Alantara Sanur, dapat disampaikan sebagai berikut:

\section{Karakteristik Responden Berdasarkan Usia}

Berdasarkan hasil olah data kuesioner, bahwa usia 20-30 tahun merupakan kelompok usia responden dengan persentase tertinggi yaitu 40\% (8 orang) dan jumlah responden dengan kelompok usia dengan persentase terendah adalah $>40$ tahun sebanyak 5\% (1 orang). Hal ini menunjukan bahwa responden dari penyebaran kuesioner yang dilakukan pada Posisi Restoran di The Alantara Sanur didominasi oleh usia 20-30 tahun.

\section{Karakteristik Responden Berdasarkan Jenis Kelamin}

Berdasarkan hasil olah data kuesioner, bahwa jenis kelamin laki=laki lebih banyak daripada perempuan yaitu 55\% (11 orang) sedangkan perempuan sebanyak $45 \%$ (9 orang). Hal ini menunjukan bahwa responden dari penyebaran kuesioner yang dilakukan pada Posisi Restoran di The Alantara Sanur didominasi oleh lakilaki.

\section{Hasil Penilaian Penerapan Kualitas Pelayanan Pramusaji}

Berdasarkan hasil kuesioner yang disebar kepada 20 orang responden, maka didapat penilaian responden terhadap 5 indikator kualitas pelayanan, diantaranya: Bukti Fisik (Tangibles), Daya Tanggap (Responsiveness), Jaminan (Assurance), 
Empati (Empathy), dan Keandalan (Reliability). Adapun hasil dari penilaian tersebut dapat dilihat pada penjelasan sebagai berikut:

1. Indikator Bukti Fisik (Tangibles)

a. Kebersihan dan kerapian di restoran

Berdasarkan hasil olah data kuesioner, bahwa kebersihan dan kerapian di Pesisi Restoran mendapat penilaian Sangat Baik sebanyak 12 dari 20 responden atau sebesar $60 \%$ dengan nilai rata-rata 3,00. Penilaian Baik sebanyak 6 dari 20 responden atau sebesar 30\% dengan nilai rata-rata 1,20. Penilaian Cukup sebanyak 2 dari 20 responden atau sebesar $10 \%$ dengan nilai rata-rata 0,30 . Dan nilai rata-rata total yaitu sebesar 4,50 yang dapat diklasifikasikan pada kategori sangat baik. Sehingga dari paparan data diatas, dapat disimpulkan bahwa Pesisi Restoran memiliki kebersihan dan kerapian yang sangat baik.

b. Kelengkapan dan kebersihan peralatan di restoran

Berdasarkan hasil olah data kuesioner, bahwa kelengkapan dan kebersihan peralatan di Pesisi Restoran mendapat penilaian Sangat Baik sebanyak 6 dari 20 responden atau sebesar 30\% dengan nilai rata-rata 1,50. Penilaian Baik sebanyak 13 dari 20 responden atau sebesar $65 \%$ dengan nilai ratarata 2,60. Penilaian Cukup sebanyak 1 dari 20 responden atau sebesar 5\% dengan nilai rata-rata 0,15 . Dan nilai rata-rata total yaitu sebesar 4,25 yang dapat diklasifikasikan pada kategori sangat baik. Sehingga dari paparan data diatas, dapat disimpulkan bahwa Pesisi Restoran memiliki kelengkapan dan kebersihan peralatan yang sangat baik.

c. Kebersihan dan kerapian pramusaji

Berdasarkan hasil olah data kuesioner, bahwa kebersihan dan kerapian pramusaji di Pesisi Restoran mendapat penilaian Sangat Baik sebanyak 13 dari 20 responden atau sebesar $65 \%$ dengan nilai rata-rata 3,25 . Penilaian Baik sebanyak 6 dari 20 responden atau sebesar 30\% dengan nilai rata-rata 1,20. Penilaian Cukup sebanyak 1 dari 20 responden atau sebesar 5\% dengan nilai rata-rata 0,15 . Dan nilai rata-rata total yaitu sebesar 4,60 yang dapat diklasifikasikan pada kategori sangat baik. Sehingga dari paparan data diatas, dapat disimpulkan bahwa pramusaji Pesisi Restoran memiliki kebersihan dan kerapian yang sangat baik.

2. Indikator Daya Tanggap (Responsiveness)

a. Pramusaji memberikan respon yang cepat untuk masalah layanan tamu

Berdasarkan hasil olah data kuesioner, bahwa kecepatan pramusaji dalam merespon tamu di Pesisi Restoran mendapat penilaian Sangat Baik sebanyak 13 dari 20 responden atau sebesar $65 \%$ dengan nilai rata-rata 3,25. Penilaian Baik sebanyak 7 dari 20 responden atau sebesar $35 \%$ dengan nilai rata-rata 1,40 . Dan nilai rata-rata total yaitu sebesar 4,65 yang dapat diklasifikasikan pada kategori sangat baik. Sehingga dari paparan data diatas, dapat disimpulkan bahwa pramusaji Pesisi Restoran memiliki kecepatan dalam merespon tamu dengan sangat baik. 
b. Pramusaji memiliki kemauan untuk memenuhi permintaan tamu dengan cepat

Berdasarkan hasil olah data kuesioner, bahwa kemauan pramusaji dalam memenuhi permintaan tamu dengan cepat di Pesisi Restoran mendapat penilaian Sangat Baik sebanyak 8 dari 20 responden atau sebesar $40 \%$ dengan nilai rata-rata 2,00. Penilaian Baik sebanyak 11 dari 20 responden atau sebesar 55\% dengan nilai rata-rata 2,20. Penilaian Cukup sebanyak 1 dari 20 responden atau sebesar 5\% dengan nilai rata-rata 0,15 . Dan nilai rata-rata total yaitu sebesar 4,35 yang dapat diklasifikasikan pada kategori sangat baik. Sehingga dari paparan data diatas, dapat disimpulkan bahwa pramusaji Pesisi Restoran memiliki kemauan memenuhi permintaan tamu dengan sangat baik.

3. Jaminan (Assurance)

a. Pramusaji bersikap ramah dan sopan dalam memberikan pelayanan

Berdasarkan hasil olah data kuesioner, bahwa keramahan dan kesopanan pramusaji dalam memberikan pelayanan di Pesisi Restoran mendapat penilaian Sangat Baik sebanyak 10 dari 20 responden atau sebesar 50\% dengan nilai rata-rata 2,50. Penilaian Baik sebanyak 8 dari 20 responden atau sebesar $40 \%$ dengan nilai rata-rata 1,60. Penilaian Cukup sebanyak 2 dari 20 responden atau sebesar $10 \%$ dengan nilai rata-rata 0,30 . Dan nilai rata-rata total yaitu sebesar 4,40 yang dapat diklasifikasikan pada kategori sangat baik. Sehingga dari paparan data diatas, dapat disimpulkan bahwa pramusaji Pesisi Restoran memiliki keramahan dan kesopanan dalam memberikan pelayanan dengan sangat baik.

b. Pramusaji menguasai produk yang tersedia di restoran

Berdasarkan hasil olah data kuesioner, bahwa penguasaan produk restoran oleh pramusaji di Pesisi Restoran mendapat penilaian Sangat Baik sebanyak 8 dari 20 responden atau sebesar $40 \%$ dengan nilai rata-rata 2,00. Penilaian Baik sebanyak 10 dari 20 responden atau sebesar $50 \%$ dengan nilai rata-rata 2,00. Penilaian Cukup sebanyak 2 dari 20 responden atau sebesar $10 \%$ dengan nilai rata-rata 0,30 . Dan nilai rata-rata total yaitu sebesar 4,30 yang dapat diklasifikasikan pada kategori sangat baik. Sehingga dari paparan data diatas, dapat disimpulkan bahwa pramusaji Pesisi Restoran menguasai produk restoran dengan sangat baik.

c. Pramusaji dapat berkomunikasi secara efektif

Berdasarkan hasil olah data kuesioner, bahwa kemampuan pramusaji dalam berkomunikasi secara efektif di Pesisi Restoran mendapat penilaian Sangat Baik sebanyak 8 dari 20 responden atau sebesar $40 \%$ dengan nilai rata-rata 2,00. Penilaian Baik sebanyak 11 dari 20 responden atau sebesar 55\% dengan nilai rata-rata 2,20. Penilaian Cukup sebanyak 1 dari 20 responden atau sebesar 5\% dengan nilai rata-rata 0,15 . Dan nilai rata-rata total yaitu sebesar 4,35 yang dapat diklasifikasikan pada kategori sangat baik. Sehingga dari paparan data diatas, dapat disimpulkan bahwa pramusaji dapat berkomunikasi secara efektif dengan sangat baik. 


\section{Empati (Empathy)}

a. Pramusaji memberikan perhatian yang bersifat individual dalam menyediakan layanan tamu

Berdasarkan hasil olah data kuesioner, bahwa pemberian perhatian dari pramusaji kepada tamu di Pesisi Restoran mendapat penilaian Sangat Baik sebanyak 11 dari 20 responden atau sebesar 55\% dengan nilai rata-rata 2,75. Penilaian Baik sebanyak 9 dari 20 responden atau sebesar $45 \%$ dengan nilai rata-rata 1,80. Dan nilai rata-rata total yaitu sebesar 4,55 yang dapat diklasifikasikan pada kategori sangat baik. Sehingga dari paparan data diatas, dapat disimpulkan bahwa pemberian perhatian dari pramusaji kepada tamu di Pesisi Restoran dinilai sangat baik.

b. Pramusaji dapat memahami kebutuhan tamu

Berdasarkan hasil olah data kuesioner, bahwa kemampuan pramusaji dalam memahami kebutuhan tamu di Pesisi Restoran mendapat penilaian Sangat Baik sebanyak 8 dari 20 responden atau sebesar $40 \%$ dengan nilai rata-rata 2,00. Penilaian Baik sebanyak 12 dari 20 responden atau sebesar $60 \%$ dengan nilai rata-rata 2,40. Dan nilai rata-rata total yaitu sebesar 4,40 yang dapat diklasifikasikan pada kategori sangat baik. Sehingga dari paparan data diatas, dapat disimpulkan bahwa kemampuan pramusaji dalam memahami kebutuhan tamu di Pesisi Restoran dinilai sangat baik.

5. Kehandalan (Reliability)

a. Pramusaji menyediakan teknik prosedur pelayanan yang sama untuk setiap tamu

Berdasarkan hasil olah data kuesioner, bahwa penyediaan prosedur pelayanan yang sama untuk setiap tamu di Pesisi Restoran mendapat penilaian Sangat Baik sebanyak 10 dari 20 responden atau sebesar 50\% dengan nilai rata-rata 2,50. Penilaian Baik sebanyak 9 dari 20 responden atau sebesar $45 \%$ dengan nilai rata-rata 1,80. Penilaian Cukup sebanyak 1 dari 20 responden atau sebesar 5\% dengan nilai rata-rata 0,15 . Dan nilai rata-rata total yaitu sebesar 4,45 yang dapat diklasifikasikan pada kategori sangat baik. Sehingga dari paparan data diatas, dapat disimpulkan bahwa penyediaan prosedur pelayanan yang sama untuk setiap tamu di Pesisi Restoran dinilai sangat baik.

b. Pramusaji tepat waktu dalam melayani tamu

Berdasarkan hasil olah data kuesioner, bahwa ketepatan waktu pramusaji dalam melayani tamu di Pesisi Restoran mendapat penilaian Sangat Baik sebanyak 8 dari 20 responden atau sebesar $40 \%$ dengan nilai rata-rata 2,00. Penilaian Baik sebanyak 11 dari 20 responden atau sebesar 55\% dengan nilai rata-rata 2,20. Penilaian Cukup sebanyak 1 dari 20 responden atau sebesar 5\% dengan nilai rata-rata 0,15 . Dan nilai rata-rata total yaitu sebesar 4,35 yang dapat diklasifikasikan pada kategori sangat baik. Sehingga dari paparan data diatas, dapat disimpulkan bahwa ketepatan waktu pramusaji dalam melayani tamu di Pesisi Restoran dinilai sangat baik. 
Berdasarkan hasil olah data kuesioner menunjukkan bahwa indikatorindikator dari setiap dimensi kualitas pelayanan pada tingkat pelayanan dinilai sangat baik oleh responden, hal ini didasarkan pada perhitungan seluruh nilai ratarata tingkat pelayanan pada angka 4,44. Nilai rata-rata terbesar pada tingkat pelayanan adalah dimensi daya tanggap (responsiveness) yaitu sebesar 4,50 yang berarti tamu merasa sangat puas dengan pelayanan yang diberikan oleh pramusaji dalam kecepatan pramusaji dalam merespon tamu dan memenuhi keinginan tamu sehingga tamu merasakan pelayanan yang diberikan oleh pramusaji dinilai sangat baik pada indikator-indikator daya tanggap (responsiveness), sedangkan nilai ratarata terkecil adalah pada dimensi jaminan (assurance) yaitu sebesar 4,35 yang berarti pada indikator jaminan ini pramusaji belum maksimal jika dibandingkan dengan indikator lain dalam memberikan pelayanan yang mengacu pada indikator jaminan yaitu pramusaji belum maksimal dalam menguasai produk-produk yang dijual di restoran, berkomunikasi dengan efektif dan keramahan pramusaji, tetapi dalam penilaian kuesioner ini tamu memberikan penilaian yang sangat baik dengan nilai total rata-rata pada indikator ini yaitu 4,35 yang tergolong indikator sangat baik.

Berdasarkan paparan data diatas, diharapkan pihak Pesisi Restoran The Alantara Sanur lebih meningkatkan tingkat kualitas pelayanan dilihat dari setiap indikatorindikator tersebut agar kedepannya setiap indikator memiliki penilaian yang lebih baik lagi sehingga tamu akan merasa lebih puas terhadap pelayanan yang diberikan oleh pramusaji.

\section{PEMBAHASAN}

Berdasarkan paparan data dan penjelasan yang diberikan pada sub bab hasil penelitian diatas, bahwa hasil tersebut sesuai dengan hasil observasi selama 3 hari yang dilakukan peneliti pada setiap pramusaji Pesisi Restoran di The Alantara Sanur yaitu pada tanggal 12-14 Mei 2021. Observasi yang dilakukan berupa pengamatan yang peneliti amati dari setiap kegiatan pelayanan yang dilakukan oleh setiap pramusaji baik itu dalam hal kebersihan, kerapian maupun pelayanan yang dilakukan pada setiap tamu berdasarkan penilaian terhadap 5 dimensi kualitas pelayanan yaitu Bukti Fisik (Tangibles), Daya Tanggap (Responsiveness), Jaminan (Assurance), Empati (Emphaty), dan Keandalan (Reliability). Berdasarkan aspek penilaian tersebut, peneliti mengamati bahwa seluruh pramusaji Pesisi Restoran telah melakukan 5 dimensi kualitas pelayanan dengan baik namun terdapat beberapa kendala seperti pada hari pertama dan hari kedua, peneliti menemukan bahwa pramusaji tidak menerapkan aspek kehandalan yaitu pada bagian ketepatan waktu dalam melayani tamu, dan pada hari kedua juga peneliti menemukan pramusaji tidak menerapkan aspek daya tanggap yaitu pada bagian memberikan respon yang cepat untuk masalah layanan tamu. Dan pada aspek lainnya seluruh pramusaji sudah berhasil menerapkannya satu persatu.

Menanggapi hal tersebut, Bapak Wayan selaku Restoran dan Bar Manajer memberi penjelasan mengenai hal tersebut, beliau menyatakan bahwa pada saat itu, pada tanggal 12 sampai 13 Mei 2021 situasi restoran sedang ramai dan krodit terlebih lagi pramusaji yang incharge sangat sedikit yaitu hanya 1 staff pramusaji 
ditambah 2 orang training sehingga dalam hal fast respon kita mengalami sedikit kendala pada hari tersebut mengingat kondisi sedang ramai, dan mengenai keterlambatan dalam melayani tamu dalam hal out makanan itu kita bergantung pada bagian food and beverage production atau kitchen, karena jika mereka cepat dalam membuat orderan maka kita sebagai pramusaji juga cepat dalam menyajikan makanan pada tamu, begitupun sebaliknya. Dan pada hari ketiga observasi, peneliti tidak menemukan suatu masalah dalam kualitas pelayanan, karena setiap pramusaji di hari tersebut sudah menerapkan kualitas pelayanan dengan baik dan sesuai dengan 5 dimensi kualitas pelayanan.

Data lain yang mendukung penelitian kualitas pelayanan ini adalah data dokumentasi berupa good guest comment yang terlampir pada lampiran 2 penelitian ini. Pada lampiran 2 tersebut terlihat tamu memberikan komentar yang positif mengenai pelayanan yang diberikan pramusaji, rata-rata dari mereka merasa puas dengan pelayanan yang diberikan. Dan beberapa dari komentar tamu tersebut memperlihatkan kepuasan mereka selama berada di hotel khususnya pelayanan makanan dan minuman sehingga memiliki keinginan untuk kembali lagi.

Hasil ini juga didukung dengan hasil wawancara yang peneliti lakukan dengan I Wayan Suata selaku Restoran dan Bar Manager Pesisi Restoran di The Alantara Sanur pada tanggal 16 Mei 2021. Bapak Wayan menyatakan bahwa seluruh pramusaji sudah mengetahui standar operasional prosedur yang diterapkan di restoran dan penerapannya selalu diawasi oleh head itu sendiri agar tidak menyimpang dari SOP itu sendiri, dan produk yang dijual di restoran itu adalah pelayanan dan produk jadi semua pramusaji sudah pasti menonjolkan kualitas pelayanan. Selain itu, Bapak Wayan sebagai restaurant manager selalu memberikan training, dan sharing hal-hal baru mengenai produk dan pelayanan khususnya bagaimana menjadi pramusaji yang memberikan kualitas pelayanan yang baik, dan dalam operasional juga selain menerapkan SOP dan kualitas pelayanan, pramusaji juga diwajibkan untuk selalu mengecek kualitas makanan dan minuman yang dihidangkan kepada tamu, tujuannya yaitu untuk menghindari komplain dari tamu, seperti jika terdapat makanan dan minuman yang tidak sesuai dengan tamu maka dapat segera kita ganti dan itu sangat meminimalisir terjadinya komplain keluar. Menurut Bapak Wayan sendiri, menerapkan kualitas pelayanan itu sangat penting mengingat di jaman sekarang kualitas adalah yang terutama kemudian produk, jika kita sudah memiliki kualitas yang bagus maka secara otomatis tamu akan kembali lagi.

Berdasarkan hasil penelitian dan pembahasan diatas, dapat disimpulkan bahwa pramusaji Pesisi Restoran di The Alantara Sanur telah menerapkan kualitas pelayanan yang sangat baik dalam memberikan pelayanan kepada tamu sehingga menghasilkan komentar positif dan penilaian yang positif dari tamu sehingga secara keseluruhan indikator-indikator yang dinilai juga memiliki hasil yang sangat baik dengan nilai total rata-rata secara keseluruhan yaitu 4,44 yang dikategorikan sangat baik.

\section{SIMPULAN}


Dari hasil penelitian dan pembahasan mengenai penerapan kualitas pelayanan pramusaji pada Pesisi Restoran di The Alantara Sanur, maka dapat ditarik kesimpulan bahwa total nilai rata-rata secara keseluruhan terhadap dimensi pelayanan pramusaji di Pesisi Restoran adalah sebesar 4,44 yang dapat dikategorikan sangat baik. Dari kelima dimensi pelayanan mendapatkan nilai ratarata sangat baik, hal ini dapat dilihat sebagai berikut:

a. Bukti Fisik (Tangible) memperoleh nilai rata-rata 4,45 yang dapat dikategorikan sangat baik.

b. Daya Tanggap (Responsiveness) memperoleh nilai rata-rata 4,50 yang dapat dikategorikan sangat baik.

c. Jaminan (Assurance) memperoleh nilai rata-rata 4,35 yang dapat dikategorikan sangat baik.

d. Empati (Empathy) memperoleh nilai rata-rata 4,48 yang dapat dikategorikan sangat baik.

e. Kehandalan (Reliability) memperoleh nilai rata-rata 4,40 yang dapat dikategorikan sangat baik

\section{SARAN}

Berdasarkan kesimpulan diatas, agar kualitas pelayanan yang diberikan oleh pramusaji Pesisi Restoran dapat dipertahankan dan ditingkatkan guna untuk tercapainya kepuasan tamu yang berkunjung ke Pesisi Restoran, maka peneliti dapat menyarankan beberapa hal sebagai berikut:

1. Pada dimensi Bukti Fisik (Tangible), hendaknya manajemen Pesisi Restoran di The Alantara Sanur dapat mempertahankan serta meningkatkan kebersihan dan kerapian restoran, kelengkapan dan kebersihan peralatan restoran, dan penampilan pramusaji mulai dari kebersihan hingga kerapian.

2. Pada dimensi Daya Tanggap (Responsiveness), hendaknya manajemen Pesisi Restoran di The Alantara Sanur dapat meningkatkan kualitas pelayanan dengan cara mengadakan program pelatihan kepada setiap pramusaji mengenai penerapan kualitas pelayanan tentang bagaimana cara menanggapi dan memenuhi kebutuhan serta permintaan tamu dengan cepat dan tepat. Selain itu, pramusaji juga harus memiliki kesediaan untuk memberikan respon cepat dan tanggap apabila tamu memerlukan bantuan.

3. Pada dimensi Jaminan (Assurance), hendaknya manajemen Pesisi Restoran di The Alantara Sanur selalu memberikan pengarahan kepada setiap pramusaji dan mengingatkan tentang cara bersikap ramah dan sopan kepada tamu, selalu melakukan review kepada setiap pramusaji mengenai product knowledge tujuannya agar pramusaji lebih memahami mengenai produkproduk apa saja yang dijual di restoran sehingga jika ada tamu yang bertanya maka pramusaji dapat menjelaskan kepada tamu, dan juga 
memberikan pelatihan mengenai komunikasi agar setiap pramusaji mampu berkomunikasi secara efektif kepada tamu.

4. Pada dimensi Empati (Empathy), hendaknya manajemen Pesisi Restoran di The Alantara Sanur memberikan pelatihan dan pengarahan kepada setiap pramusaji agar setiap pramusaji mampu memahami kebutuhan tamu tersebut guna untuk menghindari terjadinya kesalahan yang akan menyebabkan komplain. Selain itu, pramusaji juga harus memiliki sikap empati kepada setiap tamu, pramusaji harus bisa merasakan dan mengetahui hal apa yang tamu butuhkan dan sebagai pramusaji harus memenuhi hal tersebut.

5. Pada dimensi Kehandalan (Reliability), hendaknya manajemen Pesisi Restoran di The Alantara Sanur selalu mengingatkan setiap pramusaji untuk memberikan pelayanan yang sesuai dengan yang dijanjikan khususnya mengenai ketepatan waktu dalam pelayanan harus diinformasikan dengan benar dan akurat kepada tamu sehingga tamu merasa senang dan puas, selain itu juga setiap pramusaji harus menyediakan prosedur pelayanan yang sama kepada setiap tamu dengan kata lain tidak membeda-bedakan tamu yang satu dengan tamu yang lain, atau tamu lokal dengan tamu asing.

\section{DAFTAR PUSTAKA}

Agusnawar. 2000. Operasional Tata Graha. Jakarta: Gramedia Pustaka Utama. Anwar, Prabu Mangkunegara. 2002. Manajemen Sumber Daya Manusia. Bandung: PT. Remaja Rosda Karya.

Atmodjo, M.W. 2005. Restoran dan Segala Permasalahannya. Yogyakarta: Andi. Candraswari, Putu Diah. 2019. Pengaruh Pemberian Kompensasi Finansial dan Non Finansial Terhadap Kinerja Karyawan Di Best Western Kuta Villa. Denpasar: Sekolah Tinggi Pariwisata Bali Internasional (Skripsi).

Dewi, Dewa Ayu Anggistya. 2014. Pengaruh Kompetensi Kerja Terhadap Kualitas Pelayanan Pramusaji Pada Kamaya Restoran Di Kamaya Resort \& Villas Ubud. Denpasar: Sekolah Tinggi Pariwisata Bali Internasional (Skripsi).

Kotler, Philip. 2000. Marketing Management Edisi Milenium. Inc New Jersey: Prentice Hall Intl.

Pantiyasa, I Wayan. 2013. Metodologi Penelitian. Denpasar: STPBI.

Prabawati, Ida Ayu Agung Yulia. 2019. Kualitas Pelayanan Pramusaji Pada Restoran Banyubiru di The Laguna a Luxury Collection Resort and Spa Nusa Dua. Denpasar: Sekolah Tinggi Pariwisata Bali Internasional (Tugas Akhir).

Purnaya, Dr. I Gusti Ketut. 2016. Manajemen Sumber Daya Manusia. Denpasar: STPBI

Rymberthus, A.A Andrikus. 2000. Pelaksanaan Standard Operating Procedure di Department Food \& Beverage. Jakarta: Gramedia Pustaka Utama. 
Setyadi, I Made Wahyu. 2019. Kualitas Pelayanan Pramusaji di Restoran Arwana The Laguna a Luxury Collection Resort and Spa. Denpasar: Sekolah Tinggi Pariwisata Bali Intenasional (Tugas Akhir).

Soekresno dan Pendit. 2004. Petunjuk Praktek Pramusaji Food \& Beverage Service: Buku Panduan Sekolah Pariwisata dan Perhotelan. Jakarta: Gramedia Pustaka Utama.

Suadnyana, Wayan. 2020. Pantai sanur - Daya Tarik, Aktivitas Liburan Seru \& Peta Lokasi. https://www.water-sport-bali.com/pantai-sanur/ (diakses pada 27 Februari 2021).

Tjiptono, F. 1996. Strategi Bisnis Manajemen. Yogyakarta: Andi Offset.

Wardhani, Hanif. 2018. 15 Fakta Unik Tentang Bali Yang Mungkin Belum Kamu Ketahui. https://www.tripzilla.id/fakta-unik-bali/10243 (diakses pada 27 Februari 2021).

Waryono, 2018. Waiter. http://staf.unp.ac.id/artikel/16-09-2018/waiter (diakses pada 30 Januari 2021 